\title{
STUDI KUALITATIF TERHADAP INDIGENOUS PEOPLE PAPUA YANG TERPAPAR GLOBALISASI BUDAYA MELALUI RELASI SOSIALNYA DENGAN PENDATANG
}

\author{
PRT. Paramma ${ }^{1}$, Lewi Kabanga ${ }^{2}$ \\ ${ }^{1,2}$ Universitas Sains dan Teknologi Jayapura \\ Email: lewikaban@gmail.com
}

\begin{abstract}
It has become a common understanding that the phenomenon known as globalization very quickly takes over almost all aspects of human life in different parts of the world. The majority of people have realized that they are being affected by globalization so that they are usually more readily and easily adapt to a new community called global village. However, many people are still experiencing cultural shock and lack of self-confident when meeting with people from other external environments. This latter type is usually coming from isolated areas, both physically and mentally. This study aims to explore the questions raised in the community about the effects of globalization and their relationship with the social bonds between indigenous Papuan and migrants outside of Papua. In addition, this study tries to answer the scale of acceptance of indigenous Papuans on the influence of external culture. This research is expected to provide benefits to policy makers in designing social engineering in order to avoid potential open conflicts in the future. This research method was descriptive qualitative. Data was generated from research directly on the ground through in-depth interviews (IDI) and focus group discussions (FGD). This research was conducted in the city of Jayapura. The conclusion of this study consisted of 6 measured categories, namely food / cuisine, style, social lifestyle, language, music and inter-racial marriage, which showed that the exposure to cultural globalization had a positive contribution to the social relations of indigenous Papuans with immigrants.
\end{abstract}

Key Words: Globalization, Indigenous, Migrants, Social-Relation;

\section{A. PENDAHULUAN}

Popularitas kajian globalisasi hampir tidak pernah surut sejak terminologi ini pertama kali diperkenalkan empat abad yang lalu dan menjadi bagian dari manusia zaman modern hari ini. Penelusuran serius mengenai globalisasi bukanlah fenomena baru bagi masyarakat kebanyakan terutama masyarakat akademik, sehingga penelitian ini akan terbantu dengan ragam sumber penelitian sebelumnya yang tersedia cukup banyak. 
Jurnal SOSIO DIALEKTIKA 6 (1) (2021)

P-ISSN: 2540.8941 e-ISSN: 2623.2944

sosiodialektika@unwahas.ac.id
Studi Kualitatif Terhadap

Indigenous People Papua Yang

Terpapar Globalisasi Budaya

Melalui Relasi Sosialnya Dengan

Pendatang

Latar belakang penelitian ini bermula dari pertanyaan-pertanyaan sederhana seperti sudah sampai dimanakah masyarakat kita menyadari bahwa mereka secara tak terhindarkan (inevitable) telah terpapar pengaruh globalisasi, kemudian sudah sejauh mana level penerimaan mereka terhadap gelombang globalisasi disekitar mereka, serta apakah terjadi benturan antar peradaban dintara mereka sebagaimana prediksi Samuel P. Huntington dalam buku populernya "the clash of civilization and the remaking of the world order"? (Huntington, 1997).

Alasan-alasan munculnya gagasan untuk mengkaji tema dalam penelitian ini adalah untuk mendeskripsikan efek langsung dan tidak langsung dari globalisasi dalam kehidupan bermasyarakat di Papua secara khusus di kota Jayapura. Selain itu penelitian ini berusaha mencari jawaban mengenai penerimaan indigenous people Papua terhadap budaya yang dibawah oleh orang luar yang telah terpapar globalisasi.

Dari alasan-alasan diatas diharapkan penelitian ini berdampak positif terhadap harmonisasi relasi sosial antara masyarakat pendatang (migran) dengan masyarakat asli papua (indigenous Papuans) dalam berbagai segi kehidupan. Juga diharapkan bisa memberi deteksi awal (early warning) terhadap kemungkinan destruksi komunikasi antar budaya dan mencegah konflik komunal di masa yang akan datang.

Globalisasi terjadi karena adanya teknologi informasi yang meluas secara cepat. Dimana informasi tersebut masuk dari luar wilayah dan meluas ke dalam suatu wilayah. T, Doni Ermawan (2017) berpendapat bahwa globalisasi menciptakan peningkatan keterikatan dan ketergantungan antar bangsa dan manusia di seluruh dunia. Dia juga menambahkan bahwa globalisasi terjadi melalui mediasi perdangan, investasi, perjalanan, budaya popular, dan berbagai macam interaksi lainnya. Hal ini menyebabkan dunia seakan-akan sempit. Jika demikian, globalisasi memasuki 3 arena penting manusia yaitu ekonomi,, politik, dan budaya. Dan yang menjadi tulang punggung dari globalisasi adalah kekuatan teknologi dan bisnis. 
Jurnal SOSIO DIALEKTIKA 6 (1) (2021)

P-ISSN: 2540.8941 e-ISSN: 2623.2944

sosiodialektika@unwahas.ac.id
Studi Kualitatif Terhadap

Indigenous People Papua Yang

Terpapar Globalisasi Budaya

Melalui Relasi Sosialnya Dengan

Pendatang

Globalisasi yang bersentuhan dengan budaya akan disebut budaya global (global culture) dengan adanya hal tersebut maka budaya membuka dan menerima budaya luar dengan berbagai landasan alasan, termasuk perubahan, akan menyedot budaya luar dan membaurkan dengan budaya lokal. Globalisasi ini tidak serta merta menjamah seluruh aspek sehingga budaya tidak menjadi homogen dan tetap bersifat heterogen, karena budaya lokal dan budaya global dapat berjalan beriringan. Peleburan globalisasi budaya bisa menyebabkan peleburan budaya yang dikenal dengan istilah melting pot. Ritzer (2010) dalam Larasati (2018) berpendapat bahwa globalisasi budaya bisa terbentuk dari budaya yang lebih kuat.

Larasati (2018) melihat Pengaruh dan eksistensi Hallyu (Korean wave) Versus Westernisasi di Indonesia". Penilitian ini berusaha untuk menginvestigasi dampak nyata yang bersifat dominan antara budaya western dan budaya korea di Indonesia. Dengan lahirnya Hallyu (Korean Wave) yang diboncengi oleh westernisasi yang mendunia untuk masuk ke Indonesia maka adanya kolaborasi antara westernisasi dan koreanisasi mengakibatkan posisi keeksistensian salah satu budaya tersebut cenderung bertahan dan tergeser dalam kehidupan bangsa Indonesia. Untuk mengkaji topik tersebut penulis menggunakan konsep tiga scenario yang dikenal dengan "three $H$ " scenarios, Homogenitas, heterognitas dan Hybridinitas. Hasil penelitian ini menunjukkan bahwa Korean wave mulai menggeser posisi westernisasi sebagai budaya global di Indonesia yang dibuktikan dengan meningkatnya minat masyarakat Indonesia terhadap simbol-simbol kebudayaan Korea seperti musik, makanan, fashion, make up bahkan bahasa. hal ini didukung dengan adanya kesamaan faktor geografis seperti pada dunia busana. Pada budaya barat cenderung bebas dan terbuka sedangkan Korean wave cenderung tertutup.

Safitri (2011), Melihat pada sudut lain bahwa masalah sosial, juga terjadi secara umum di Papua, dan konflik masyarakta adat Papua dengan PT Freeport Indonesia terjadi karena adanya kesenjangan keikut sertaan secara langsung masyarakat Papua di dalamnya. Sehingga salah satu cara 
Jurnal SOSIO DIALEKTIKA 6 (1) (2021)

P-ISSN: 2540.8941 e-ISSN: 2623.2944

sosiodialektika@unwahas.ac.id
Studi Kualitatif Terhadap

Indigenous People Papua Yang

Terpapar Globalisasi Budaya

Melalui Relasi Sosialnya Dengan

Pendatang

strategis untuk meredam konflik tersebut yaitu dengan menggunakan kebijakan budaya di mana adanya nilai tambah yang diberikan PT Freeport untuk menimbulkan rasa rangkulan demi menumbuhkembangkan sense of belonging kepada masyarakat dan adat. Serta melibatkan secara aktif masyarakat adat dalam proyek yang dijalankan di Freeport. Sejalan dengan Anisa \& et al., (2018) mengidentifikasi upaya eksistensi dan kendala masyarakat adat di kampung tujuh di tengah globalisasi di desa wisata Ngalanggeran, Gunung Kidul dengan menggunakan metode etnografi. Disimpulkan masyarakat Kampung Tujuh masih mempertahankan keaslian adat istiadat serta menjalankam nilai-nilai adat dari leluhur. Bentuk tradisi yang masih dipertahankan adalah rasulan (upacara syukuran atas hasil panen), tingalan (syukur atas ulang tahun dalam bentuk ritual untuk memotong ayam jawa), bersih makam, dan melakukan penghormatan dan menjaga tempat-tempat yang dianggap sakral seperti sumber mata air.

Rusniati (2015) menganalisa tentang kajian kritis terhadap Pemikiran A. Malik Fadjar dalam menghadapi tantangan globalisasi dalam pendidikan nasional. Problem utama lahirnya pemikiran A Malik Fadjar, pakar dan praktisi pendidikan yang gagasan dan kebijakannya selalu mendapat respon positif, adalah pendidikan nasional masih bersifat konvensional yang menekankan kecerdasan dan kurang memberikan perhatian dalam perkembangan bakat dan kreatifitas peserta didik. Sehingga tantangan yang muncul dalam pendidikan adalah melakukan perubahan dan penyesuaian sistem pendidikan nasional. Hasil penelitian ini menunjukkan bahwa paradigma pendidikan A. Malik Fadjar bersifat holistik yaitu pendidikan yang humanis, liberatif, integralistik, multikultural, dan futuristik baik pada aspek visi-misi, kelembagaan, manajemen, pola interaksi pendidikan dan kurikulum pendidikan.

Lestari (2018), menganalisa“"Peran Teknologi dalam Pendidikan di Era Globalisasi. Tujuan dari penelitian ini adalah mencari dampak globalisasi penggunaan teknologi dalam dunia pendidikan. Dampak yang disajikan dilatarbelakangi dari isu-isu teknologi dalam pendidikan. Isu tersebut adalah 
Jurnal SOSIO DIALEKTIKA 6 (1) (2021)

P-ISSN: 2540.8941 e-ISSN: 2623.2944

sosiodialektika@unwahas.ac.id
Studi Kualitatif Terhadap

Indigenous People Papua Yang

Terpapar Globalisasi Budaya

Melalui Relasi Sosialnya Dengan

Pendatang

teknologi sebagai alat sekaligus media yang fundamental yang meningkatakan kualitas pendidikan sekaligus merupakan media yang merusak mental. Oleh sebabnya itu, hasil penelitian ini menunjukkan dampak positif-negatif teknologi dalam dunia pendidikan. Sebagai dampak positif teknologi terasa lebih efesien dalam bentuk waktu, biaya, logistik, dan masalah-masalah institusi. Sedangkan dampak negatif teknologi yaitu teknologi bisa mengubah kehidupan sosial seperti pengguanaan internet mengubah perilaku yang lebih konsumtif.

Secara garis besar, kesamaan penelitian di atas dan yang sementara berlangsung adalah mencari dampak dari globalisasi yang mempengaruhi kehidupan secara umum di Indonesia. Baik secara positif dan negatif, penelitian di atas umumnya disajikan secara general kepada objeknya sedangkan pada peniltian ini akan disajikan secara spesifik yaitu dampak yang terjadi hanya kepada penduduk indigenous/penduduk asli Papua. Sehingga ada respond yang menonjol yang membedakan dari penduduk yang terpapar secara langsung baik secara positif dan negatif setelah melakukan pembauran dengan masyarakat sekelilingnya.

\section{B. METODE PENELITIAN}

Penelitian ini mengugunakan metode deskripsi kualitatif untuk menjabarkan relasi sosial anatara indigenous Papua dengan migran. Walaupun ide penelitian ini mencakup isu mengenai Papua secara umum, namun lokasi penelitian akan bertempat di sekitar Kota Jayapura. Pemilihan Kota Jayapura didasari pemikiran bahwa kota ini merupakan "melting pot" semua suku dari seluruh wilayah di Indonesia. Di kota Jayapura juga terdapat pusat paguyuban atau ikatan keluarga suku lain dari luar Papua. Untuk kepentingan penelitian ini, lokasi wawancara IDI dan FGD difokuskan pada beberapa tempat seperti asrama mahasiswa, kampus, dan gereja. Selain itu dalam mengumpulkan data, mengingat situasi dan kondisi pandemi covid-19, peneliti menerapkan IDI dan FGD secara daring, via zoom. 
Jurnal SOSIO DIALEKTIKA 6 (1) (2021)

P-ISSN: 2540.8941 e-ISSN: 2623.2944

sosiodialektika@unwahas.ac.id
Studi Kualitatif Terhadap

Indigenous People Papua Yang

Terpapar Globalisasi Budaya

Melalui Relasi Sosialnya Dengan

Pendatang

Yang menjadi sampel dalam penelitian ini adalah (1) Anggota Masyarakat umum, (2) Indigenous Papuan yang meliputi 7 daerah adat Papua, dan (3) Informan Kunci yang meliputi akademisi, tokoh adat, tokoh pemuda, dan politisi. Dalam menentukan sampel untuk menggali data secara wawancara mendalam atau IDI, dan FGD, Peneliti menggunakan jargon seperti di dalam table di bawah ini

Tabel 1. Sampel IDI dan FGD

\begin{tabular}{|l|l|l|}
\hline \multicolumn{1}{|c|}{ Wawancara } & IDI & \multicolumn{1}{|c|}{ FGD } \\
\hline $\begin{array}{l}\text { Anggota } \\
\text { Masyarakat } \\
\text { Umum }\end{array}$ & $\begin{array}{l}\text { Max 5 FGD x 7 } \\
\text { orang = 35 orang }\end{array}$ \\
\hline 7 wilayah adat & $\begin{array}{l}2 \text { orang x 7 wilayah } \\
\text { adat = 14 orang }\end{array}$ & - \\
\hline Informan Kunci & Max. 12 Orang & - \\
\hline
\end{tabular}

Data dikumpulkan dengan menggunakan teknik interview mendalam yang disebut In depth Interview/IDI. Teknik ini melibatkan sampel dari 7 wilayah adat yang dipilih dan informan kunci yang terdiri dari mahasiswa dan pemuda. Teknik ini dilaksanakan dengan model panduan semi terstruktur yaitu wawancara dijalankan sambal menggembangkan topik untuk mencari inti atau jawaban yang diinginkan. Selain itu, teknik diskusi kelompok terarah (FGD) dijalankan secara luring dan daring pada sampel dari berbagai latar belakang suku antara Papua dan Non-Papua. Teknik ini dijalankan dengan menggunakan panduan wawancara yaitu peneliti bertindak sebagai moderator dan notulen. Dari kedua teknik tersebut dijalankan dan difasilitasi dengan sistem rekaman.

Sumber data berasal dari hasil wawancara lapangan melalui wawancara IDI dan FGD yang direkam. Data yang direkam kemudian ditraskrip. Data dikelolah dengan menggunakan sistem coding untuk mengkalsifikasikan bentuk globalisasi yang dirasakan secara langsung sekaligus efek dan relasi sosialnya dengan masyarakat sekitar. Hasil dari klasifiaksi tersebut dipaduhkan dengan catatan lapangan dari notulen dan 
Jurnal SOSIO DIALEKTIKA 6 (1) (2021)

P-ISSN: 2540.8941 e-ISSN: 2623.2944

sosiodialektika@unwahas.ac.id
Studi Kualitatif Terhadap

Indigenous People Papua Yang

Terpapar Globalisasi Budaya

Melalui Relasi Sosialnya Dengan

Pendatang

dianalisa eksistansi penerimaan globalisasinya, masyarakat Papua, dan bentuk relasi yang terbentuk dalam masyarkat yang majemuk. Alur dari pengambilan data sampai pada tahap analisi dapat dilihat pada bagan di bawah ini.

\section{HASIL DAN PEMBAHASAN}

Adanya paparan/efek globalisasi di Papua dan pengaruhnya terhadap relasi sosial antara orang indigenous dengan migran dapat dilihat pada 6 isu utama. Keenam isu tersebut dianggap level paparannya paling banyak mempengaruhi hubungan sosial di Papua. Globalisasi Makanan/masakan, style and appearances, pola hidup sosial, Bahasa, Preferensi musik serta perkawinan antar ras adalah bagian yang akan didiskusikan dalam penelitian ini. Hasil penelitian ini menunjukkan adanya paparan globalisasi dan relasi sosial diperjelas dengan adanya hubungan timbal-balik yang terjadi diantara migran dan indigenous Papuans, selain itu adanya peran migran memperkenalkan, menyebarkan, mempopulerkan, dan memadukan asalusul, dan kegunaan dari barang/ bentuk globalisasi tersebut.

\section{(1) Globalisasi Makanan}

Sibal, V (2018) menjelaskan bahwa orang selalu menghubungkan budaya dan etnik mereka melalui makanan. Makanan sering digunakan sebagai alat untuk melanggengkan identitas budaya mereka. Orang dari kultur yang berbeda memakan makanan yang berbeda pula. Makanan yang mengglobal di Papua karena tidak lepas dari peranan kota dan migran. Jenis makanan yang digemari oleh orang indigenous di Jayapura, di luar dari makanan pokok mereka, adalah Sup, Bakso, Roti Tawar, Nasi kuning, Bakwan, Tempe, KFC, dan Makanan Warung. Jika dilihat dari asal-usul makanan tersebut maka makanan di atas nampak berasal dari laur Papua kemudian menjadi bagian yang tidak terpisahkan dari kehidupan mereka lagi.

Tabel 2. Asal Makanan 
Jurnal SOSIO DIALEKTIKA 6 (1) (2021)

P-ISSN: 2540.8941 e-ISSN: 2623.2944

sosiodialektika@unwahas.ac.id
Studi Kualitatif Terhadap

Indigenous People Papua Yang

Terpapar Globalisasi Budaya

Melalui Relasi Sosialnya Dengan

Pendatang

\begin{tabular}{cll}
\hline NO & \multicolumn{1}{c}{ Jenis Makanan } & \multicolumn{1}{c}{ Asal Mula } \\
\hline 1 & Sup & Prancis \\
\hline 2 & Bakso & $\begin{array}{l}\text { Indonesia (Jawa), makanan } \\
\text { derivasi dari China }\end{array}$ \\
\hline 3 & Roti Tawar & Mesir (Mesopotamia) \\
\hline 4 & Nasi Kuning & Jawa, Jogjakarta, dan Bali \\
\hline 5 & Bakwan & China \\
\hline 6 & Tempe & Indonesia (Jawa) \\
\hline 7 & KFC & Indiana-Amerika \\
\hline
\end{tabular}

Adapun alasan mengapa mereka memilih masakan/makanan

tersebut didominasi oleh alasan lebih praktis (cepat saji), lebih ekonomis (murah),mudah dijangkau (warung ada dimana-mana), dan sudah kenal baik dengan penjual (kedekatan sosial).

“...Kami biasa bulak balik terus to jadi dia kenal, kalau untuk nama ya dia tidak tau kalau muka ya dia kenal tapi dia macam tidak lihat-lihat orang to pertanyaannya kan macam orang kios atau orang warung...(FGD,

ABHM0106)".

Selain makanan yang mengglobal di atas, makanan tradisional mereka juga merupakan warisan leluhur yang perlu mereka jaga baik secara cita rasa dan nilainya. Oleh sebab itu, di papua makanan masih menjadi bagian yang tak terpisahkan dari ritual adat dan praktekpraktek tertentu seperti yang diungkapkan oleh partisipan yang mengatakan bahwa

“......makan untuk tradisonal sebenarnya kita ada di jayapura kita juga rindu,rindu untuk makan itu dan kita lebih senang komsumsi makanan lokal dari pada makanan dari luar ya macam-macam itu, Cuma karena ekonomi yang memaksa kita untuk harus makan ada seadanya begitu...... (FGD, ABHM0107)". 
Jurnal SOSIO DIALEKTIKA 6 (1) (2021)

P-ISSN: 2540.8941 e-ISSN: 2623.2944

sosiodialektika@unwahas.ac.id
Studi Kualitatif Terhadap

Indigenous People Papua Yang

Terpapar Globalisasi Budaya

Melalui Relasi Sosialnya Dengan

Pendatang

Dengan demikian bisa dikatakan bahwa makanan yang mengglobal kini merambah sampai ke seluruh penjuru termasuk di Papua, terbukti dari hampir keseluruhan partisipan dalam penelitian memilih makanan yang diolah secara nontradisional. Para partisipan juga mengakui bahwa sebenarnya mereka masih merindukan makanan olahan seperti dikampung masing-masing, namun tidak mudah untuk mendapatkan bahan di kota sehingga mereka memilih makanan yang lebih praktis dan mudah dijangkau.

(2) Style, Fashion, dan Penampilan

Bagian ini bertujuan untuk mengeksplorasi preferensi gaya dan penampilan melalui pertanyaan permulaan seperti: siapa aktor atau public figure yang paling anda kagumi dalam segi style dan penampilan fisik? Juga partisipan mendapatkan gambar/ foto model sebagai referensi style kotemporer dan tradisional. Kebanyakan dari mereka sepakat bahwa actor/public figure yang dikagumi merupakan actor/actress keturunan Afro-American, penyanyi reggae seperti Lucky Dube dan Bob Marley, Actor/actress India, Actor/actress Korea, dan Penyanyi Lokal seperti Agnes monica.

Pada bagian ini preferensi partisipan cukup beragam, seperti yang diungkapkan oleh partisipan FGD sebagai berikut:

“........saya lebih suka dengan gaya korea dengan gaya-

gaya amerika hitam” (FGD, umum, AUHT0209)

"saya lebih suka perempuan afrika karena mereka punya

body-body yang saya suka sekali” ((FGD, AUHT0203)

"saya lebih suka sama agnes monika ....." (FGD,

AUHT0205) “.......Saya lebih tertarik ke fashionnya

Korea, saya lebih suka ke cara berpakaiannya,

berbusananya,....." (FGD, AFHM0206)

ragam respon partisipan diatas menunjukkan paparan globalisasi terhadap orang indegeneous cukup beragam dalam hal pilihan style sehingga gap dalam isu globalisasi pada segmen ini tidak begitu 
Jurnal SOSIO DIALEKTIKA 6 (1) (2021)

P-ISSN: 2540.8941 e-ISSN: 2623.2944

sosiodialektika@unwahas.ac.id
Studi Kualitatif Terhadap

Indigenous People Papua Yang

Terpapar Globalisasi Budaya

Melalui Relasi Sosialnya Dengan

Pendatang

kontras satu sama lain. Pada bagian ini menunjukkan bahwa variasi gaya, busana, dan fesion dipengaruhi karena adanya perkembangan modernisasi melalui perkembangan, penyebaran teknologi digital, dan kesenangan mereka akan idola atau publik figur tertentu. Selain itu, penyebaran model busana yang sudah menyebar masif di Jayapura memaksa dan menuntut mereka untuk menggambil bagian dalam rana gloabalisasi ini dengan cara mengkombinasi dengan kearifan lokal yang mereka punyai seperti noken.

\section{(3) Globalisasi Pola Hidup Bersosial}

Hidup bersosial adalah hidup yang saling berinteraksi antara satu dengan yang lainnya. Terjalinnya komunikasi yang baik, saling bersimpati, dan harmonisasi dalam masyarakat merupakan hasil dari hidup bersosial. Pada umumnya, bentuk kehidupan dibagi dalam hidup berkelompok yang berlandaskan pada asas kekeluargaan dan hidup yang bersifat individualistik. Bahasan pada bagian ini menunjukkan hidup yang berkelompok, individual, dan perpaduan antara kedua sifat tersebut.

(a) Individualistik

Pemahaman bahwa ciri masyarakat yang telah terpapar globalisasi adalah mereka akan semakin individualis, namun penelitian ini mendapati beberapa poin menarik yang merupakan kebalikan dari pemahaman umum diatas. Justru mereka yang datang dari pedalaman umumnya mereka memiliki sifat individualistik, hal ini mungkin disebabkan oleh karena kondisi topografi yang terisolasi dari lingkungan sosial lebih luas dan juga faktor demografi yang mana mereka hidup di wilayah pedesaan (rural area). Seperti yang diungkapakan partisipan bahwa "nanti sampai di kota baru mulai mengenal hidup kolektif": 
Jurnal SOSIO DIALEKTIKA 6 (1) (2021)

P-ISSN: 2540.8941 e-ISSN: 2623.2944

sosiodialektika@unwahas.ac.id
Studi Kualitatif Terhadap

Indigenous People Papua Yang

Terpapar Globalisasi Budaya

Melalui Relasi Sosialnya Dengan

Pendatang

"dari kecil suka sendiri, dengan saudara-saudara

juga saya tidak bergaul, cuma datang kesini itu yang

saya bisa bergaul' AUHT0201"

Hilde Nafstad mengutip Bauman dalam penelitiannya mengatakan bahwa dewasa ini, ideology pasar kapitalis membawa semangat individualisme secara luar biasa, (Nafstad Hilde, dkk, 2012). Meskipun demikian hal ini tidak (belum) terjadi di Papua secara meyeluruh. Individualisme masih dipahami sebagai paham egosentris yang merugikan. Seperti hasil wawancara dibawah ini:

“........kita mau sendiri juga tidak bisa mungkin ada yang mau sendiri tapi kita factor ekonomi dan lainlain juga kita tidak bisa sendiri macam- macam itu......." (IDI, Pemuda, AB03).

\section{(b) Kolektif}

Hampir semua partisipan setuju bahwa hidup kolektif adalah keharusan oleh karena berbagai alasan. Partisipan menyamaratakan antara hidup kolektif dengan gotong royong (saling membantu) dan individulistik sama dengan memikirkan diri sendiri.

"ah kalau dari saya senang hidup berkelompok

karna .....dan juga kalau kita tidak ada yang kita

punya pasti mereka melengkapi begitu” (FGD,

ZHT0101).

(c) Campuran

Namun ada juga partisipan yang mengaku bahwa keduanya (individualistik dan Kolektif) memiliki keuntungan. Ada masa dimana mereka individual dan ada masa untuk hidup kolektif. Sikap ini merupakan peralihan atau pergesaran dari kolektif ke individual. 
Jurnal SOSIO DIALEKTIKA 6 (1) (2021)

P-ISSN: 2540.8941 e-ISSN: 2623.2944

sosiodialektika@unwahas.ac.id
Studi Kualitatif Terhadap

Indigenous People Papua Yang

Terpapar Globalisasi Budaya

Melalui Relasi Sosialnya Dengan

Pendatang

$$
\begin{aligned}
& \text { "saya lebih suka keduanya individual dengan } \\
& \text { kelompok tergantung } \\
& \text { waktunya" (IDI, pemudi OSO4). }
\end{aligned}
$$

Pada dasarnya hidup bersoalisasi adalah hidup yang harus berdamai dengan lingkungan. Hidup dimana manusia didorong untuk beradaptasi dengan lingkungan dengan memperhatikan nilai, dan norma kemasyarakatan. Jika di kota, Jayapura, manusia atau orang indigenous harus beradaptasi dengan keadaan lingkungan perkotaan dengan tetap memperhatikan keharmonisan dalam masyarakat.

\section{(4) Globalisasi Bahasa}

Bahasa adalah alat komunikasi yang digunakan untuk mentransfer informasi yang berupa pesan, pengetahuan dan dan ide. Bentuk bahasa dibagi dalam dua bagian yaitu bahasa verbal dan nonverbal. Di Papua mempunyai ragam bahasa baik secara verbal, simbol maupun non-verbal. Pemilihan bahasa juga disertai dengan manfaat dan nilai bahasa tersebut.

"Kalau misalnya di asrama itu kita sering pakai Bahasa nasional tapi, kalau pertemuan secara keluarga kita kadang pakai Bahasa daerah sendiri....( AFHMO201)”

“....mungkin bisa mengerti Bahasa daerah tapi saya tidak bisa membalas.... (AFHMO208)"

"kalua kita satu suku maybrat hampir kita tidak ....

"sedikit mengerti tapi tidak bisa balas.... (AUHT0203)",

"Setiap hari pakai Bahasa Indonesia (AUHT0208)"

Dari data di atas ada hal yang menarik yang menjadi perhatian dan menjadi fenomena bahasa. Dalam istilah sosiolinguistik dikenal dengan istilah "language change" dan "language choice". Fenomena Bahasa yang ditampilkan di data di atas akan diklasifikasi penggunaannya berdasarkan kedua istilah tersebut. Untuk menampilkan dan mengklasifikasikan kelompok berdasarkan "change dan choice". 
Jurnal SOSIO DIALEKTIKA 6 (1) (2021)

P-ISSN: 2540.8941 e-ISSN: 2623.2944

sosiodialektika@unwahas.ac.id
Studi Kualitatif Terhadap

Indigenous People Papua Yang

Terpapar Globalisasi Budaya

Melalui Relasi Sosialnya Dengan

Pendatang

Banyak hal yang mempengaruhi Bahasa berubah bahkan Bahasa bisa berujung pada kepunahan. Statement yang mengatakan bahwa "paham akan Bahasa ibu tapi tidak bisa membalas" adalah bukti bahwa adanya pergesaran factor internal dan eksternal bahasa sebagai fakta bahwa latar belakang dan kontekstual tempat mereka tinggal mempengaruhi bahasa tersebut bergeser dan berganti. Melirik akan pendapat Graddol (2004) bahwa factor pertumbuhan penduduk, perkembangan kota, ekonomi, organisasi sosial, dan perkembangan globalisasi adalah faktor jangka pendek yang bisa mengubah bahasa. Kedua level tersebut adalah status, demografi, dukungan institusional, persamaan dan perbedaan budaya yang sangat releven adalah level pertama yaitu level yang disebut language change (Gile 1977). Sedangkan level kedua adalah disebabkan karena hubungan sebab akibat, dan perubahan diantara masyrakat sebagai reaksi terhadap perubahan lingkungan, (Appel and Muysken 1987).

Jadi dapat disimpulkan bahwa terjadinya "language change" pada orang indigenous Papua di kota Jayapura karena disebakan oleh demografi yaitu adanya laju pergerakan penduduk yang membawa Bahasa dan menggeser bahasa ibu. Selain itu peranan kota, ekonomi dan gerakan globalisasi memaksa menggeser akan keeksistensian bahasa lokal mereka. Oleh sebabnya itu untuk melestarikan bahasa lokal tersebut perlu adanya revitalisasi sebagai langkah awal untuk mencegah bahasa ibu mereka punah.

Mengenai kemapuan menggunakan dua bahasa disebut bilingualisme di mana kedua bahasa tersebut dapat dipergunakan secara bergantian, berselang-seling dan penyisipan bahasa tertentu di atas bahasa dominan yang digunakan.

"Hamers and Blanc (1987) said that bilingualism as linguistic community in which two language exist in contact as the result that both language can be used in one interaction”. 
Jurnal SOSIO DIALEKTIKA 6 (1) (2021)

P-ISSN: 2540.8941 e-ISSN: 2623.2944

sosiodialektika@unwahas.ac.id
Studi Kualitatif Terhadap

Indigenous People Papua Yang

Terpapar Globalisasi Budaya

Melalui Relasi Sosialnya Dengan

Pendatang

Hal yang mempengaruhi terjadinya language choice adalah adanya penunjukan status pada pembicara. Status yang dimaksud adalah kemampuan menggunakan dua bahasa secara fasi baik secara leksikal maupuan secara wacana panjang. Selain itu juga menunjukkan adanya benefit yang didapatkan dalam menggunakan bahasa tersebut secara periodik. Dalam hal ini menunjukkan bahwa mahasiswa Papua di kota mempunyai status menggunakan bahasa nasional dan bahasa lokal mereka dalam berinteraksi dan bersosialisasi. Juga adanya benefit atau keuntungan yang berupa cost atau harga yang mereka peroleh dengan menggunakan kedua Bahasa tersebut. Cost yang mereka peroleh adalah mereka memperluas jaringan mereka dalam merekrut dan meyeleksi pertemanan di tengah kota yang bersifat heterogen. Melakukan aktivitas mereka sebagai mahasiwa dengan kolaborasi Bahasa mereka adalah suatu keuntungan sendiri untuk berbaur dan bersosialisasi.

\section{(5) Preferensi Genre Musik}

Preferensi musik oleh individu menunjukkan adanya latar belakang dan kegemaran yang menggugah jiwa dan perasaan oleh penikmat musik tertentu. Oleh orang indigenous di Papua di kota Jayapura, mereka mengekspresikan adanya genre musik yang mengglobal. Seperti reggae, hip-hop, pop, rock dan country. Latar belakang dan asal musik itu berasal. 
Jurnal SOSIO DIALEKTIKA 6 (1) (2021)

P-ISSN: 2540.8941 e-ISSN: 2623.2944

sosiodialektika@unwahas.ac.id
Studi Kualitatif Terhadap

Indigenous People Papua Yang

Terpapar Globalisasi Budaya

Melalui Relasi Sosialnya Dengan

Pendatang

Tabel 3. Asal Musik

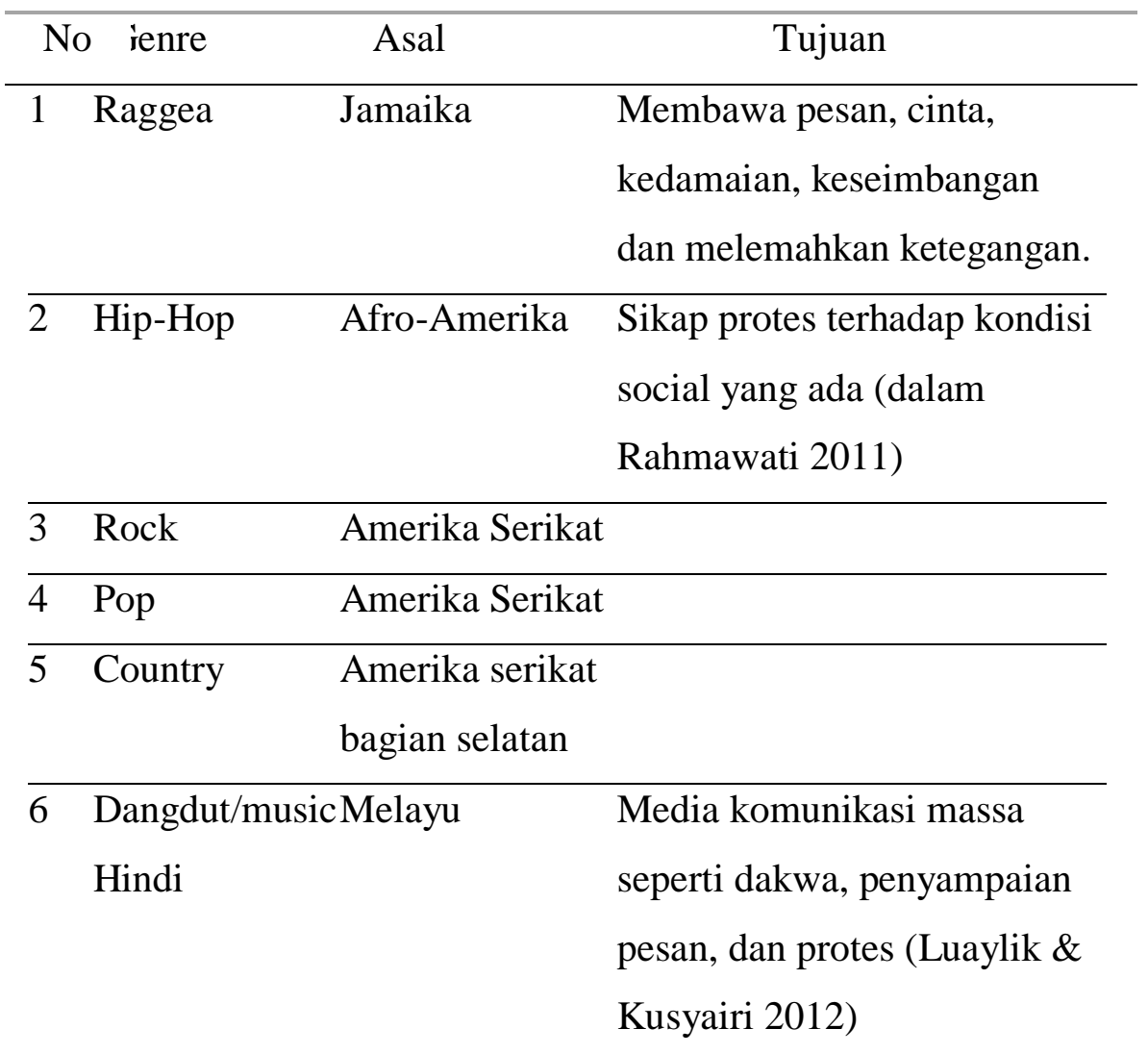

Genre musik yang disenangi oleh penduduk asli Papua adalah genre musik reggae, Pop, country Hip-Hop dan dangdut. Genre reggae adalah music yang berasal dari Jamaika yang mengkombinasikan iringan musik tradisional Afrika, Amerika, dan Blues serta lagu rakyat Jamaika, "Reg-ay" (Reggae). Reggae diduga berasal dari pengucapan dalam logat Afrika, yaitu "Ragged" (Gerak gerak kagok seperti menghentak badan oleh orang yang menari dengan iringan musik). Peminatan musik ini adalah karena adanya kesamaan anatara orang Papua asli dengan Jamaika. Kesamaan tersebut bisa berupa appreansis dan budaya. Budaya orang Jamaika adalah budaya yang bersifat kolektif dengan melaksanakan tradisi ritual pada pada periode waktu tertentu, beragama mayoritas Kristen, hobby yang berorentasi pada bola dan golf, seni yang berlandaskan sejarah (Jascha 2016). Sedangkan bentuk topografi negara Jamaika 
Jurnal SOSIO DIALEKTIKA 6 (1) (2021)

P-ISSN: 2540.8941 e-ISSN: 2623.2944

sosiodialektika@unwahas.ac.id
Studi Kualitatif Terhadap

Indigenous People Papua Yang

Terpapar Globalisasi Budaya

Melalui Relasi Sosialnya Dengan

Pendatang

adalah merupakan daerah pegunungan dengan penduduk mayoritas Afro-Amerika.

Disamping itu, jika diperhatikan minat dan bakat, masyrakat Papua cenderung merujuk pada musik dan olahraga. Musik yang disukai masyarakat Papua umumnya bentuk musik yang memberikan sentakan dan goyangan. Sehingga genre music yang berhubungan dan melahirkan goyangan adalah bentuk musik yang identik dengan masyarakat yang beretnis negro malanesia (melanosoid) dan AfroAmerika. Selaras dengan genre Hiphop, genre ini berasal dari Amerika yang dipopulerkan oleh orang-orang Amerika yang berkulit hitam atau etnis Afro. Latar belakang munculnya musik ini karena tidak lapas dari sejarah silam penduduk Amerika yang didominasi oleh 2 etnis besar. Sedangakan musik lain tidak sesuai dengan latar belakang budaya mereka yang mengutamakan nilai moral.

Hubungan dengan relasi sosial dan budaya musik yang berada di perkotaan bagi penduduk asli Papua adalah musik seperti Pop, rock, dangdut diperkenalkan oleh masyarakat non-pribumi Papua. Dengan adanya minat dan preferensi musik yang sama membuat persamaan dan pembauran budaya dan interaksi sosial diantara mereka. Selain itu teknologi adalah media utama yang merupakan sumber munculnya segala informasi yang dibutuhkan termasuk genre musik yang sudah beredar dan berkembang diselurh dunia.

Jadi genre musik dan preferensinya diakibtakan karena adanya persamaan faktor yang melatar belakangi beredar dan berkembangnya genre musik tertentu. Persamaan tersebut berupa persamaan budaya, topografi, kegemaran dengan orentasi kepeminatan akan musik dan persamaan kecintaan pada genre tertentu antara etnis pribumi dan non pribumi. Persamaan tersebut tidak lepas dari keberadaan perkembangan informasi dan teknologi yang sudah dirasakan sepenuhnya oleh penduduk asli Papua setelah berada di tengah-tengah kota. 
Jurnal SOSIO DIALEKTIKA 6 (1) (2021)

P-ISSN: 2540.8941 e-ISSN: 2623.2944

sosiodialektika@unwahas.ac.id
Studi Kualitatif Terhadap

Indigenous People Papua Yang

Terpapar Globalisasi Budaya

Melalui Relasi Sosialnya Dengan

Pendatang

(6) Pernikahan Antar Ras (Inter Racial-Marriage)

Ada dua reaksi yang muncul sebagai sikap dan pandangan mereka mengenai pernikahan antar dua ras yang berbeda. Ada yang bersikap keras menolak perkawinan antar ras yang berbeda dan di lain sisi adapula yang sangat merespon positif akan hal tersebut. Respon tersebut akan berdampak positif bahkan negatif bagi pribadi masingmasing individu. Perkawinan antar ras adalah perkawinan yang bersifat fenomenal tidak hanya pada belahan Indonesia tetapi mencakup seluruh dunia, termasuk Papua. Pernikahan antar ras yang berbeda tidak jauh halnya dengan pernikahan antar budaya dan suku karena istilah ini adalah istilah yang menekankan ras berarti menekankan budaya pada etnis tertentu. Adanya respon penolakan dan penerimaan pernikahan antar suku yang berbeda tidak jauh pada alasan yang mendasar pada kepentingan pribadi secara khusus.

Wang (2012) Tuapattinaya dan Hartati (2014) meneliti tiga orang wanita Jawa yang menikah dengan pria beda etnis menunjukkan bahwa dua dari tiga subjek dalam penelitian tersebut menghadapi pertentangan internal dalam keluarga, dari orangtua merek, yang menginginkan subjek untuk menikah dengan pria Jawa. Sedikit berbeda dengan penelitian kualitatif Apriani, Sakti, \& Fauziah (2013) yang mengemukakan bahwa permasalahan dalam perkawinan antarbudaya seperti pada wanita Jawa yang menikah dengan pria keturunan Tionghoa adalah adanya prasangka keluarga yang beranggapan bahwa wanita jawa adalah wanita boros.

Di Papua juga menunjukkan adanya sikap yang menerima dan menolak pernikahan antar ras yang berbeda. Pada data di bawah ini menunjukkan respon penolakan mengenai perkawinan antar ras yang berbeda.

“Tidak setuju...... Kita orang Papua sudah sedikit jadi harus kawin Kembali pada sesama suku....... tidak kawin 
Jurnal SOSIO DIALEKTIKA 6 (1) (2021)

P-ISSN: 2540.8941 e-ISSN: 2623.2944

sosiodialektika@unwahas.ac.id
Studi Kualitatif Terhadap

Indigenous People Papua Yang

Terpapar Globalisasi Budaya

Melalui Relasi Sosialnya Dengan

Pendatang

pada suku sendiri sudah tidak dianggap, dan tidak mampu (AUHT0214)"

“sudah punya pengalaman, mama sudah tidak dianggap macam su tidak ada begitu (AUHT0210)"

“ .... Paling baik itu kita kawin sesame Papua supaya kita punya ras tidak hilang (AUHT0210)"

“...... adat masih kuat jadi jadi harus kawin suku sendiri ..... (AUHT0203)”

“ ...... Tidak setuju karena dapat menghilangkan rasa tau orang asli Fak-Fak...(AFHM0208).

"saya lebih suka menikah sesame keluarga sendiri, karena kita di Fak-Fak itu sudah punya pesanan sendiri dari orang tua......( AFHM0205)

“.... Tidak setuju Tidak boleh karena nati kita punya ras punah (ABHM0101)

Hampir semua statement penolakan berdasarkan pada factor internal suku. Adanya pandangan yang mengatakan bahwa ras Papua akan punah yang membawa kekwatiran dan menimbulakan penolakan keras akan pernikahan antar ras yang berbeda. Selain itu ikatan norma pada suku mereka masih melekat dengan erat sehingga konsekuensi ketika melanggar akan norma itu adalah pengucilan dari keluarga dan masyarakat sekitar. Jati diri adalah salah satu factor yang merujuk pada status dalam masyarakat bahwa melanggar norma dan menikah dengan ras lain adalah anggapan bahwa tidak mampu dalam memenuhi representatika mas kawin pada suku tersebut.

Berbeda dengan yang setuju dengan pernikahan antar ras yang berbeda. Mereka cenderung lepas dari norma dan mengacuh pada permasalahan inner individu yaitu perasaan. Berikut adalah pendapat yang serupa dari respon penerimaan/ setuju terhadap pernikahan antar ras 
Jurnal SOSIO DIALEKTIKA 6 (1) (2021)

P-ISSN: 2540.8941 e-ISSN: 2623.2944

sosiodialektika@unwahas.ac.id
Studi Kualitatif Terhadap

Indigenous People Papua Yang

Terpapar Globalisasi Budaya

Melalui Relasi Sosialnya Dengan

Pendatang

"kalau saya tergantung cinta, kita tidak bisa memaksa

(AUHT0201)"

"saya senang denga ras Eropa (AUHT0205)"

".... Urusan menikah .... Ya jodoh di tangan Tuhan. Jadi

mau menikah dengan orang luar kah, orang dalam kah

...... (AFHM0206)"

"kalua dari saya, menikah dengan siapa saja itu dari diri

sendiri, dari individu ..... (AFHM0204)"

"Setuju karena ras kulit hitam sama ras kulit putih kalau

kawin pasti mengubah keturunan (ZHT0101)"

Suatu hal menarik pada data di atas, partisipan pada penelitian di

atas adalah didominasi dari gender laki-laki. Mereka cenderung berpikir bebas dan luar dari norma yang yang mengikat. Umumnya wanita berpendapat bahwa menikah di luar ras/suku dapat atau berpotensi menghilangkan ras asli mereka sendiri. Dain lain sisi lakilaki berpendapat bahwa pernikahan itu tergantung pada sikap personal masing-masing. Sikap ini menunjukkan bahwa keturunan dan generasi mereka kedepannya, perempuan lebih cenderung mempertahankan adat dan kelangsungan ras mereka sedangkan laki-laki cenderung membuka diri.

Jadi perkawinan beda ras terjadi karena faktor internal yang menganggap bahwa jodoh yang mempertemukan mereka. Secara kontekstual bahwa Papua adalah masih merupakan dari transmigrasi di mana berbagai suku bertransmigrasi ke Papua karena alasan pemertaan penduduk dan ekonomi. Kesempatan ini yang merupakan terjadinya relasi sosial bahkan tidak jarang mereka melakukan perkawinan silang antar ras, budaya, dan suku. Berbeda halnya dengan yang menolak perkawinan antar suka karane adanya norma yang kuat dan usaha untuk melestarikan budaya dan ras mereka. 
Jurnal SOSIO DIALEKTIKA 6 (1) (2021)

P-ISSN: 2540.8941 e-ISSN: 2623.2944

sosiodialektika@unwahas.ac.id
Studi Kualitatif Terhadap

Indigenous People Papua Yang

Terpapar Globalisasi Budaya

Melalui Relasi Sosialnya Dengan

Pendatang

\section{SIMPULAN}

Globalisasi merupakan perubahan yang dialami masyarakat di dunia dengan tidak memperhatikan batas-batas geografi lagi. Globalisasi mengacu pada kondisi sosial karena adanya koneksi antara satu dengan lainnya yang meliputi aspek budaya, ekonomi, bahkan politik. Dampak globalisasi juga sudah terasa di Jayapura, Papua. Hadirnya gloabalisasi tersebut karena peran teknologi, dan inetraksi sosial dalam masyarakat. Sehingga relasi sosial antara orang indigenous dan migran merupakan salah satu media penyebaran dari perubahan. Makanan adalah salah satu contoh sederhana terjalinnya interaksi sosial antara orang indegenous dan migran, dimana migran memperkenalkan makanan luar Papau karena sifat yang praktis dan ekonomis. Selain itu, budaya berbusana juga menambah kasana perubahan karena adanya sifat yang konsumtif meniru dan menyamai idola public figure tertentu. Perubahan mengenai bahasa dinilai dari fungsi dan manfaat dari bahasa yang digunakan sebagai sarana bersosialisasi. Perubahan preferensi pola hidup dan musik didasarkan pada keadaan dan suasana hati. Di mana kehidupan sosial didasari pada adaptasi di mana mereka berineteraksi dan bersosialisasi. Laki-laki cenderung menerima dan membuka perubahan dalam hal pernikahan antar ras dan budaya tapi sisi lain, wanita cenderung mempertahankan pernikahan internal ras Papua karena alasan yang asumtif dan quantitative, ras Papua semakin berkurang. Sehingga penelitian ini menunjukkan bahwa perubahan terjadi di Papua karena campur tangan migran dalam bentuk langsung dan tidak langsung seperti pada bidang jasa, komersil, dan integrasi budaya.

\section{DAFTAR PUSTAKA}

Apriani, N., Sakti, H., \& Fauziah, N. Penyesuaian Diri Wanita Etnis Jawa yang Menikah dengan Pria Etnis Cina. Empati, 2(4), 305-315, 2013.

Eka Pratiwi, Anisa. Eksistensi Masyarakat Adat di tengah Globalisasi. Jurnal Civics: Media Kajian Kewarganegaraan vol.15 No.2 Tahun 2018/95-102, 2018. 
Jurnal SOSIO DIALEKTIKA 6 (1) (2021)

P-ISSN: 2540.8941 e-ISSN: 2623.2944

sosiodialektika@unwahas.ac.id
Studi Kualitatif Terhadap

Indigenous People Papua Yang

Terpapar Globalisasi Budaya

Melalui Relasi Sosialnya Dengan

Pendatang

Tersedia di https://journal.uny.ac.id/index.php/civics/index

Hamers J.F \& Blanc M.H. Biliguality and Bilingualism. Cambridge University Press, 1987.

Huntington, Samuel P. The Clash of Civilization and the Remarking of World Order. Penerbit Qalam. 1996.

Graddol, D. The Future of Language. A journal of Science 303, 1329-1331. (doi:10.1126/scince.1096549, 2004.

Giles, H. Language, Ethnicity, and Intergroup Relations. New York: Academic Press, 1987.

Jascha. Orang jamaika, Tradisi dan Budaya. Jacoy's Bloc, 2016. tersedia pada. http://jacoyy.blogspot.com/2016/12/v-behaviorurldefaultvmlo_28.html

Larasati, Dinda. Globalisasi Budaya da Identitas: Pengaruh da Eksistensi Hallyu (Korean Wave) Versus Westernisasi di Indonesia. Jurnal Hubungan Internasional Tahun XI, No.1, Januari-Juni, 2018.

Lestari, Sudarsri. Peran Teknologi dalam Pendiidkan di Era Globalisasi. Jurnal Pendidikan Agama Islam, "Edureligia”, Vol. 2, No.2 Juli- Desember, 2018.

Luaylik, F \& Khusyairi, J.A.. Perkembangan Music Dangdut Indonesia 1960AN1990AN. Jurnal Varleden, Vol 1 No 1Desember 2012: 1-109, 2012.

Nafstad, Hilde E. Communal Values and Individualism in Our Era of Globalization: A Comparative Longitudinal Study of Three Different Societies, CHAP, vol 3, 2012.

Rahmawati, L. Yulia. HipHop Jawa sebagai Pembentuk Identitas Kelompok Jogja Hip-Hop Foundation. Skripsi. Universitas Jogjakarta, 2011.

Tersedia:

http://eprints.uny.ac.id/22409/1/HIP\%20HOP\%20JAWA\%20SEBAGAI\%2 OPEMBENTUK\%20IDENTITAS\%20KELOMPOK\%20JHF.pdf

Rusniati. Pendidikan Nasional dan Tantangan Globalisasi: Kajian Kritis terhadap Pemikiran A. Malik Fadjar. Jurnal Ilmiah DIDAKTIKA Agustus 2015 Vol 16, No.1, 105-128, 2015. 
Jurnal SOSIO DIALEKTIKA 6 (1) (2021)

P-ISSN: 2540.8941 e-ISSN: 2623.2944

sosiodialektika@unwahas.ac.id
Studi Kualitatif Terhadap

Indigenous People Papua Yang

Terpapar Globalisasi Budaya

Melalui Relasi Sosialnya Dengan

Pendatang

Safitri, Nita. Masalah Sosial dan Konflik Masyarakat Adat Papua dengan PT Freeport Indonesia (Tinjauan Antropologis). Perspektif Vol 4 No. 1 ISSN 2088-0328, 2011.

Sibal,Vatika, Food: Identity of Culture and Religion, Jour, July-Aug, Volume 6, 2018.

T, D. Ermawan. Pengaruh Eksistensi Kebudayaan Daerah di Indonesia, Jurnal Kajian Lemhanas RI Edisi 32 Desember, 2017.

Tuapattinaya, Y. I. F., \& Hartati, S. Pengambilan Keputusan untuk Menikah Beda Etnis: Studi Fenomenologis pada Perempuan Jawa. Jurnal Psikologi Undip, 13(1), 34-41, 2014.

Wang, W. The Rise of Intermarriage. Washington, DC: Pew Research Center.

Retrieved August, 13, 2012. 